\title{
Development, characterization, and cross-amplification of polymorphic microsatellite markers for North American Trachymyrmex and Mycetomoellerius ants
}

\author{
Alix E. Matthews, Chase Rowan, Colby Stone, Katrin Kellner and Jon N. Seal ${ }^{*}$ (]
}

\begin{abstract}
Objective: The objective of this study is to develop and identify polymorphic microsatellite markers for fungus-gardening (attine) ants in the genus Trachymyrmex sensu lato. These ants are important ecosystem engineers and have been a model group for understanding complex symbiotic systems, but very little is understood about the intraspecific genetic patterns across most North American attine species. These microsatellite markers will help to better study intraspecific population genetic structure, gene flow, mating habits, and phylogeographic patterns in these species and potentially other congeners.

Results: Using next-generation sequencing techniques, we identified 17 and 12 polymorphic microsatellite markers from T. septentrionalis and Mycetomoellerius (formerly Trachymyrmex) turrifex, respectively, and assessed the genetic diversity of each marker. We also analyzed the cross-amplification success of the T. septentrionalis markers in two other closely related Trachymyrmex species, and identified 10 and 12 polymorphic markers for T. arizonensis and T. pomonae, respectively.
\end{abstract}

Keywords: Attini, Fungus-gardening ant, Intraspecific genetic diversity, Microsatellites, Population genetics

\section{Introduction}

Fungus-gardening ants (tribe Attini) have been subject to decades of research elucidating their major evolutionary transitions and radiations [1-5]. Despite these revolutionary advances, most attine research has occurred at higher taxonomic levels (species or higher). Consequently, we know very little about the microevolutionary processes that may underlie macroevolutionary (phylogenetic) patterns. This lack of understanding is partially technical since most genetic markers used to construct phylogenies typically exhibit little intraspecific variation, for both the ants and fungi [2, 6-8]. Mitochondrial

*Correspondence: trachymyrmex@gmail.com

Department of Biology, The University of Texas at Tyler, Tyler, TX, USA
DNA (mtDNA) markers, while useful for large scale geographic studies [9-11], may be generally problematic because some attines may have nuclear-incorporated mtDNA-like sequences or whose genomes contain pseudogenes [7, 12]. Moreover, mtDNA is maternally inherited, which may or may not be indicative of intraspecific patterns of gene flow since male and female ants are known to exhibit different patterns of gene flow [13-15]. Finer-level intraspecific examinations have typically required specific diploid markers such as microsatellites or single-nucleotide polymorphisms (SNPs) [16-19]. Both approaches represent co-dominant expression and genome-wide distributions, but microsatellites are short, non-coding, highly variable repetitive motifs [20], whereas SNPs are shorter and found throughout coding and non-coding genomic regions [21]. 
SNPs are popular in the genomics age because of the large quantities of potentially informative sites quickly generated in a single sequencing run, but they require considerable time and effort to identify and analyze, and are typically restricted to single studies. Conversely, microsatellite markers, once developed, can be used repeatedly in multiple studies, which may reduce their overall expense on a per-project basis [22]. Moreover, recent comparative studies in insects, fungi, and birds reported no major population genetic structural differences between these two approaches [23-26], or that more SNPs were required to produce the same information as a single microsatellite marker [27].

Traditional microsatellite development techniques (i.e., constructing libraries, cloning) have yielded polymorphic microsatellite markers for both higher and lower attines [28-32]. However, because these markers were developed for tropical attines, they may or may not be useful for North American species (J.N. Seal, unpublished observations), which tend to belong to phylogenetically distinct lineages [3, 33]. Next-generation sequencing (NGS) techniques have revolutionized microsatellite marker development in terms of decreased time and cost, and increased quantity of potential markers [34-36], although only a few studies have utilized these techniques for attines. Extensive marker sets exist for Acromyrmex lundii [37], Atta laevigata [38], and two species in the lower attine genus Mycocepurus [18, 39].

Here, our aim was to use NGS techniques to develop microsatellite markers for two additional attine species, Trachymyrmex septentrionalis and Mycetomoellerius turrifex. Both are common and ecologically important fungus-gardening ants throughout southeastern North America [10, 40, 41]. We also explored the potential for cross-amplification of the T. septentrionalis markers in two closely related species: T. arizonensis and T. pomonae. These three species belong to Trachymyrmex sensu stricto, unlike M. turrifex which belongs to a new genus, Mycetomoellerius [3, 33, 42]. These markers will provide a new tool to study patterns of attine intraspecific genetic variation and phylogeographic structure.

\section{Main text}

\section{Methods}

Primer sets were developed from a single T. septentrionalis forager collected in north Florida ([10] Site C; $30.2796,-84.9004)$ and a single $M$. turrifex forager collected in central Texas (University of Texas at Austin; $30.2861,-97.7297)$. Illumina sequencing and primer design were conducted at the Savannah River Ecology Laboratory (University of Georgia, USA) in the Molecular Ecology Laboratory. A Covaris S220 Focused-ultrasonicator sheared $1 \mu \mathrm{g}$ of genomic DNA to prepare an
Illumina paired-end shotgun library following standard Illumina TruSeq DNA Library Kit protocols and using a multiplex identifier adaptor index. Sequencing was conducted on an Illumina HiSeq 3000 platform (San Diego, CA, USA) producing 100-bp paired-end reads. PAL FINDER v.0.02.03 [43] was used to analyze five million resulting reads, and those with di-, tri-, tetra-, penta-, and hexanucleotide microsatellites were extracted. Positive reads were batched to a local installation of Primer3 v.2.0.0 [44, 45] for primer design. Markers for which the primer sequence only occurred three or four times in the five million reads were selected to avoid duplication. From this selection of 9293 (T. septentrionalis) and 6943 (M. turrifex) markers, we chose a subset to test (46 for $T$. septentrionalis; 20 for M. turrifex) following an M13-tail PCR protocol [46].

We extracted genomic DNA from individual worker ants (from restricted portions of their respective ranges; Additional file 1) preserved in $95 \%$ ethanol at $-20{ }^{\circ} \mathrm{C}$ using a QIAamp DNA Micro Kit (QIAGEN). In particular, ants used in the development of T. septentrionalis markers were all collected in Florida (i.e., not Texas) (Table 1). For all species, the $10 \mu \mathrm{L}$ PCR mix contained $1 \mu \mathrm{L}$ of 10X PCR buffer (1.0X; Applied Biosystems), $1 \mu \mathrm{L}$ Bioline ${ }^{\circledR}$ dNTP mix (1 mM each; $0.1 \mathrm{mM}$ proportional to total), $1.5 \mu \mathrm{L}$ of $25 \mathrm{mM} \mathrm{MgCl} 2$ (3.75 mM; Applied Biosystems), $0.5 \mu \mathrm{L}$ of $20 \mu \mathrm{M}$ BSA $(1 \mu \mathrm{M}$; New England Biolabs), $0.3 \mu \mathrm{L}$ of $2 \mu \mathrm{M}$ tag-labeled primer $(0.06 \mu \mathrm{M}$; forward primer with M13-tail), $0.6 \mu \mathrm{L}$ of a $2 \mu \mathrm{M}$ universal dye-labeled primer $(0.12 \mu \mathrm{M}$; FAM label with M13-tail), $1 \mu \mathrm{L}$ of $2 \mu \mathrm{M}$ unlabeled primer $(0.2 \mu \mathrm{M}$; reverse primer $)$, $0.1 \mu \mathrm{L}$ of Taq polymerase (0.5 U; Applied Biosystems), and $1 \mu \mathrm{L}$ of DNA template. PCR cycling conditions consisted of an initial denaturation of $4 \mathrm{~min}$ at $95{ }^{\circ} \mathrm{C}, 25$ (or 30) cycles of $30 \mathrm{~s}$ at $95{ }^{\circ} \mathrm{C}, 45 \mathrm{~s}$ at the primer-specific annealing temperature identified by a temperature gradient program, $45 \mathrm{~s}$ at $72{ }^{\circ} \mathrm{C}$, then 8 cycles of $30 \mathrm{~s}$ at $95{ }^{\circ} \mathrm{C}$, $45 \mathrm{~s}$ at $53{ }^{\circ} \mathrm{C}$, and $45 \mathrm{~s}$ at $72{ }^{\circ} \mathrm{C}$, and a final extension of 5 min at $72{ }^{\circ} \mathrm{C}$. PCR products were run on an Applied Biosystems 3730 Genetic Analyzer and fragments were sized with LIZ600 size standard at the University of Texas at Austin DNA Sequencing Facility.

We scored alleles in Geneious v.10.2.3 [47]. For markers that resulted in high quality PCR product and exhibited polymorphism, we measured genetic variability for each species. We estimated the number of alleles per locus $(K)$, observed and expected heterozygosity $\left(\mathrm{H}_{\mathrm{o}}\right.$ and $\left.\mathrm{H}_{\mathrm{e}}\right)$, and the probability of identity (PI; the probability of two independent samples having the same genotype) using GenAlEx v.6.5 [48, 49]. Sample sizes (numbers of individuals tested) for each marker are provided (Tables 1 and 2, Additional files 2 and 3). We assessed deviations from Hardy-Weinberg equilibrium (HWE) and tested 
Table 1 Trachymyrmex septentrionalis polymorphic microsatellite markers analyzed for Trachymyrmex septentrionalis ants

\begin{tabular}{|c|c|c|c|c|c|c|c|c|c|}
\hline Marker & Primer sequence $5^{\prime}->3^{\prime}$ & $\begin{array}{l}\text { Repeat } \\
\text { motif }\end{array}$ & $\mathrm{T}_{\mathrm{m}}\left({ }^{\circ} \mathrm{C}\right)$ & Size (bp) & $\mathrm{N}$ & K & $\mathrm{H}_{\mathrm{o}}$ & $\mathrm{H}_{\mathrm{e}}$ & PI \\
\hline $\mathrm{Ts}^{\mathrm{a}, \mathrm{b}, \mathrm{c}}$ & $\begin{array}{l}\text { F: GCGCGGTTGTTCTTTATGG } \\
\text { R:TTGTATTCTTTGTCATACAGTACGTTGC }\end{array}$ & ATTTT & 60.5 & $264-292$ & 25 & 12 & 0.68 & 0.88 & 0.03 \\
\hline$T s 4^{b, c}$ & $\begin{array}{l}\text { F: CTTTGAAATCGTCATCGCGG } \\
\text { R: ACGCCCACACGTATACCACC }\end{array}$ & TCGGC & 57.3 & $242-266$ & 25 & 11 & 0.56 & 0.87 & 0.03 \\
\hline Ts $5^{\mathrm{a}, \mathrm{c}}$ & $\begin{array}{l}\text { F: CCACCTTGGTAACTGTCGCC } \\
\text { R: CTTTGAAATCGTCATCGCGG }\end{array}$ & TCGGC & 60.5 & $230-256$ & 48 & 11 & 0.67 & 0.81 & 0.06 \\
\hline $\operatorname{Ts} 11^{b, c}$ & $\begin{array}{l}\text { F: GCAGATACAAACGTCCTACGTGC } \\
\text { R: CGCACATTTGTGACGGACG }\end{array}$ & TGCG & 66.4 & $274-358$ & 20 & 13 & 0.45 & 0.91 & 0.02 \\
\hline $\operatorname{Ts} 12^{b, c}$ & $\begin{array}{l}\text { F: ATTCCTGGCACGGATACACG } \\
\text { R: ACTCTATTGTTGCGCACCGC }\end{array}$ & ATAC & 61.3 & $164-214$ & 26 & 9 & 0.35 & 0.65 & 0.16 \\
\hline $\operatorname{Ts} 21^{c}$ & $\begin{array}{l}\text { F: CCATCCCAACCATCCTGG } \\
\text { R:TTACGATCAGGAGAGCGTGC }\end{array}$ & AGCC & 65.2 & $302-326$ & 45 & 11 & 0.76 & 0.82 & 0.05 \\
\hline $\operatorname{Ts} 25^{c}$ & $\begin{array}{l}\text { F: CGTAAATTAAAGTGCACAGTCCG } \\
\text { R: GATCGCGATTTGGTGATACG }\end{array}$ & TCTG & 61.3 & $286-346$ & 51 & 18 & 0.78 & 0.86 & 0.03 \\
\hline $\operatorname{Ts} 32^{b, c}$ & $\begin{array}{l}\text { F: ATAACAAGCGGCAGCATCG } \\
\text { R: ATTTCGAACTCGCCGGTAGC }\end{array}$ & TTGG & 59.4 & $200-242$ & 49 & 15 & 0.76 & 0.85 & 0.04 \\
\hline Ts33 & $\begin{array}{l}\text { F: AATCAAATGCTTGCGTGTGC } \\
\text { R: CCGGTTAGAAGAAACAGGCG }\end{array}$ & TGCG & 60.5 & $248-296$ & 51 & 15 & 0.71 & 0.73 & 0.09 \\
\hline$T s 34^{b, c}$ & $\begin{array}{l}\text { F: GTGAGGGAATGAGAGGGAGG } \\
\text { R: TGGTAATGATCGGTACATGATGC }\end{array}$ & TGCG & 61.3 & $246-490$ & 27 & 12 & 0.11 & 0.81 & 0.06 \\
\hline $\mathrm{Ts} 35^{\mathrm{b}, \mathrm{c}}$ & $\begin{array}{l}\text { F: TGCTCGATTCGGACACGG } \\
\text { R: CTCACAGCGGAGACAAAGGC }\end{array}$ & ACCG & 60.5 & $188-300$ & 49 & 14 & 0.89 & 0.76 & 0.08 \\
\hline$T s 36^{b, c}$ & $\begin{array}{l}\text { F: TGTAGGGATTTAGATGCGGC } \\
\text { R:TAGCCAGACCTCGTACTTCG }\end{array}$ & TGCG & 59.4 & $166-210$ & 13 & 9 & 0.15 & 0.85 & 0.04 \\
\hline Ts $39^{c}$ & $\begin{array}{l}\text { F: CTAACAAGATGCGCAGCCC } \\
\text { R:TCGAATAATCCAGTCGTGTCG }\end{array}$ & TGCC & 61.3 & $234-350$ & 50 & 30 & 0.84 & 0.94 & 0.01 \\
\hline Ts41 & $\begin{array}{l}\text { F: TTAACGTCGGCATAATTTCGG } \\
\text { R: CAATTGACTACGCAGGAGCG }\end{array}$ & TGCC & 61.3 & $206-236$ & 46 & 14 & 0.78 & 0.82 & 0.05 \\
\hline Ts $43^{c}$ & $\begin{array}{l}\text { F: CGTCTTTATATTGTATTTGCTTGATACGC } \\
\text { R: GTCCATGCACACGTCCAGC }\end{array}$ & TGCG & 61.3 & $246-358$ & 47 & 33 & 0.72 & 0.94 & 0.01 \\
\hline$T s 45^{b, c}$ & $\begin{array}{l}\text { F: CGTGTCAAGTATGTTCCCGC } \\
\text { R: AGTTTCAGGCGCAGGTAGC }\end{array}$ & TGCG & 61.3 & $174-316$ & 48 & 28 & 0.60 & 0.89 & 0.02 \\
\hline Ts $46^{c}$ & $\begin{array}{l}\text { F: GTACGCACATCGTGCTAAACG } \\
\text { R: AGCGGTGGTGGTTTCACG }\end{array}$ & TGCG & 60.5 & $310-348$ & 46 & 20 & 0.78 & 0.92 & 0.01 \\
\hline
\end{tabular}

Details include: marker information, primer sequences, repeat motif, annealing temperature ( $\left.T_{m}\right)$, size range of observed alleles given in base pairs (bp), number of individuals genotyped $(\mathrm{N})$, number of alleles observed $(\mathrm{K})$, observed heterozygosity $\left(\mathrm{H}_{\mathrm{o}}\right)$, expected heterozygosity $\left(\mathrm{H}_{\mathrm{e}}\right)$, and probability of identity $(\mathrm{PI})$

a Indicates that 30 cycles were used in the PCR profile

b Indicates deviation from Hardy-Weinberg expectations after Bonferroni corrections

c Indicates the marker shows evidence of null alleles

for linkage disequilibrium (LD) across all pairs of markers using GENEPOP v.4.2 [50] employing Bonferroni corrections for multiple comparisons. The presence of null alleles was assessed using Microchecker [51].

\section{Results}

For Trachymyrmex septentrionalis markers tested on T. septentrionalis ants, 37 of the original 46 positively amplified with 17 being reliably amplified and scored. The other 20 either showed weak amplification, weak polymorphism (2-4 alleles per marker), monomorphism, or multi-peak profiles. The number of alleles across all samples of the 17 reliable markers ranged from 9 to
33 (average $=16.2$ ). $\mathrm{H}_{\mathrm{o}}$ varied from 0.11 to 0.89 (average $=0.62$ ), while $\mathrm{H}_{\mathrm{e}}$ ranged from 0.65 to 0.94 (average $=0.84)$. After Bonferroni correction, 9 markers showed significant deviations from HWE. There were two cases of LD detected across the 136 paired markers (between Ts4 and Ts5, and Ts3 and Ts43; Table 1; Additional file 4). Most of the loci tested significantly for the presence of null alleles, which suggests that $T$. septentrionalis may have even higher allelic diversity than what we captured in our sampling (Table 1).

Of the 20 original Mycetomoellerius turrifex markers, 17 positively amplified with 12 reliably amplified and scored. The number of alleles across all samples ranged 
Table 2 Mycetomoellerius turrifex polymorphic microsatellite markers analyzed for Mycetomoellerius turrifex ants

\begin{tabular}{|c|c|c|c|c|c|c|c|c|c|}
\hline Marker & Primer sequence $5^{\prime}->3^{\prime}$ & Repeat motif & $\mathrm{T}_{\mathrm{m}}\left({ }^{\circ} \mathrm{C}\right)$ & Size (bp) & $\mathbf{N}$ & K & $\mathrm{H}_{\mathrm{o}}$ & $\mathrm{H}_{\mathbf{e}}$ & $\mathrm{PI}$ \\
\hline $\mathrm{Tt} 5$ & $\begin{array}{l}\text { F: ACGGAATGTGTTAACGTGCG } \\
\text { R:TATGTGCTCGTCGTTCTCGC }\end{array}$ & $\mathrm{TGCG}$ & 60.5 & $254-322$ & 14 & 10 & 0.71 & 0.86 & 0.04 \\
\hline $\mathrm{Tt} 10^{\mathrm{b}, \mathrm{c}}$ & $\begin{array}{l}\text { F: ACCGGAGAGCGGTAGAGACC } \\
\text { R:TACCCGGCCATTAGAACTCC }\end{array}$ & AGGT & 58.3 & $286-320$ & 16 & 11 & 0.5 & 0.85 & 0.04 \\
\hline Tt18 & $\begin{array}{l}\text { F: GGTGATGGTCGATAGTTTCCG } \\
\text { R: ACGACGTATGGGTTCGTGC }\end{array}$ & AACG & 60.5 & $196-244$ & 16 & 7 & 0.44 & 0.58 & 0.20 \\
\hline Tt20 & $\begin{array}{l}\text { F: ATGCAGAGTCAGAGGACCGC } \\
\text { R: GAATTGTCTCCACATTATCAAGGG }\end{array}$ & $\mathrm{TGCG}$ & 60.5 & $218-236$ & 15 & 7 & 0.67 & 0.78 & 0.08 \\
\hline $\mathrm{Tt} 2^{\mathrm{b}, \mathrm{c}}$ & $\begin{array}{l}\text { F: AATGTCGGACGTTTATGGTCG } \\
\text { R: GTATCATCGGCACTGCAACG }\end{array}$ & TTGCG & 56.2 & $266-314$ & 16 & 7 & 0.44 & 0.77 & 0.09 \\
\hline $\mathrm{Tt} 7^{\mathrm{a}, \mathrm{b}, \mathrm{c}}$ & $\begin{array}{l}\text { F: GCAGTATGACTTCTGATCCTTTCG } \\
\text { R: CACGTTAATCCAGCACTCCG }\end{array}$ & $\mathrm{TGCG}$ & 66.2 & $156-176$ & 15 & 4 & 0.20 & 0.58 & 0.26 \\
\hline $\mathrm{Tt}^{\mathrm{a}}$ & $\begin{array}{l}\text { F: ACGCACTGTGTATGTGTGCG } \\
\text { R: AGCATATAAGTACGAATAACTGAGATTGG }\end{array}$ & $\mathrm{TGCG}$ & 66.2 & $188-264$ & 10 & 12 & 0.70 & 0.83 & 0.04 \\
\hline Tt16 & $\begin{array}{l}\text { F: TCGATTTATTAGAAAGGCTTGCG } \\
\text { R:TGCACGAGAGTGTTTGTAGCC }\end{array}$ & AGTG & 55.1 & $272-288$ & 13 & 5 & 0.54 & 0.74 & 0.11 \\
\hline$T t 6^{b, c}$ & $\begin{array}{l}\text { F: TTATATCGATGGCTTCCCACC } \\
\text { R: CCCTCTCGATATCTACTCGGTACG }\end{array}$ & AGGT & 57.3 & $318-358$ & 15 & 11 & 0.27 & 0.85 & 0.04 \\
\hline $\mathrm{Tt} 14^{\mathrm{a}}$ & $\begin{array}{l}\text { F: AAGTCGCGTAATGACGATGC } \\
\text { R: GAGATATACCTGATTCAACGTCGC }\end{array}$ & ATAC & 57.3 & $256-378$ & 15 & 10 & 0.60 & 0.77 & 0.08 \\
\hline $\mathrm{Tt} 15^{\mathrm{a}, \mathrm{b}, \mathrm{c}}$ & $\begin{array}{l}\text { F: TGCCTTCATATATGTGCCTTCG } \\
\text { R: TGTCGTTAAGAGTTACAGAACAGGG }\end{array}$ & TGCG & 65.3 & $238-304$ & 12 & 12 & 0.42 & 0.88 & 0.03 \\
\hline $\mathrm{Tt} 17^{\mathrm{b}, \mathrm{c}}$ & $\begin{array}{l}\text { F: TCACTCAAATCGAATATGTAGATGAGG } \\
\text { R: CCCACAGTAATGTCCTAGTAATGTCC }\end{array}$ & TGCG & 64.4 & $148-198$ & 15 & 11 & 0.47 & 0.88 & 0.03 \\
\hline
\end{tabular}

Details include: marker information, primer sequences, repeat motif, annealing temperature $\left(T_{m}\right)$, size range of observed alleles given in base pairs (bp), number of individuals genotyped $(\mathrm{N})$, number of alleles observed $(\mathrm{K})$, observed heterozygosity $\left(\mathrm{H}_{\mathrm{o}}\right)$, expected heterozygosity $\left(\mathrm{H}_{\mathrm{e}}\right)$, and probability of identity $(\mathrm{PI})$

a Indicates that 30 cycles were used in the PCR profile

b Indicates deviation from Hardy-Weinberg expectations after Bonferroni corrections

c Indicates the marker shows evidence of null alleles

from 4 to 12 (average $=8.9$ ). $\mathrm{H}_{\mathrm{o}}$ varied from 0.2 to 0.71 (average $=0.49$ ), while $\mathrm{H}_{\mathrm{e}}$ ranged from 0.58 to 0.88 (average $=0.78$ ). After Bonferroni correction, 6 markers showed significant deviations from HWE. There were no cases of LD detected across the 66 paired markers (Table 2; Additional file 4). In contrast to T. septentrionalis, the frequency of null alleles was lower in M. turrifex (Table 2).

We tested cross-species amplification of the $46 \mathrm{~T}$. septentrionalis markers developed here in both $T$. arizonensis and T. pomonae. For T. arizonensis $(\mathrm{n}=8), 24$ markers were positively amplified with 10 reliably scored. Of those 10, all revealed at least 2 alleles, 8 revealed 3 or more alleles, and 9 exhibited some heterozygosity. There were 9 markers in HWE and one violated HWE (Ts38). There was no LD (Additional files 2, 4). For T. pomonae $(\mathrm{n}=6), 23$ markers were successfully amplified and 12 were reliably scored. Of those 12 , all revealed at least 2 alleles, 8 revealed 3 or more alleles, and 10 exhibited some heterozygosity. There were 10 in HWE, one violated HWE (also Ts38), and one could not be computed (Ts7) because there was only one copy of the second allele. There was no LD (Additional files 3, 4). Only one of the loci in T. pomonae and only two in T. arizonensis appeared to have null alleles; this likely results from examining ants collected across a few hectares of pine oak forest (Southwest Research Station) (Additional files 2 and 3$)$.

\section{Discussion}

These newly developed microsatellite markers provide a promising new tool for population genetic, mating, dispersal, and phylogeographic studies of Trachymyrmex septentrionalis and Mycetomoellerius turrifex populations across their ranges. Positive cross-species amplification also indicates that some of the T. septentrionalis markers appear to be conserved in at least two other congeneric species ( $T$. arizonensis and T. pomonae). This indicates that future analyses for additional individuals across a wider geographic region may be informative for understanding similar questions for T. arizonensis and $T$. pomonae and perhaps other closely related Trachymyrmex. It also seems likely that the markers developed here for M. turrifex should cross amplify in closely related 
Mycetomoellerius species, such as the highly studied $M$. zeteki [42, 52, 53], among others.

While all markers across all four species showed polymorphism/allelic variation, several markers (particularly within T. septentrionalis) were hypervariable (over 20 alleles per locus; Table 1). These hypervariable markers, collectively with other polymorphic markers, may be informative for investigating intraspecific dynamics at an especially fine-scale (e.g., mating habits such as multiple-mating or multiple-queen hypotheses by comparing relatedness of individuals within colonies). Despite the extensive polymorphism illustrated by these markers, evidence of null alleles suggests that more alleles may be discovered. The frequency of null alleles may be more pronounced in populations that already demonstrate significant genetic structure [54].

The new markers developed here may also be used in conjunction with mtDNA to better understand dispersal, signatures of population expansion or contraction, and phylogeographic history. For example, male and female ants of several species may mediate gene flow differentially through sex-specific dispersal patterns $[13,14$, 55-57], but this has yet been tested in Trachymyrmex or Mycetomoellerius ants. By employing marker systems with different modes of inheritance, we may be able to discern how ecological dispersal patterns influence ant genetic structure across populations.

In a phylogeographic context, the application of both maternally and biparentally inherited markers may also help to uncover and track the progression of previously unrecognized or poorly understood historical processes such as species origin, divergence, colonization, and genetic drift. For example, the extensive evidence for null alleles in T. septentrionalis is likely driven by phylogeographic structure in this species across the relatively restricted range examined in this study (northern Florida) [10]. We explored the 17 T. septentrionalis markers across a small subset (total $n=12$ ) of T. septentrionalis ants from Texas as compared to a random subset of $T$. septentrionalis ants from Florida. The allelic diversity appears to be much higher in Florida than in Texas (see Additional file 5), which may suggest some fundamental genomic differences in populations east and west of the Mississippi River. These preliminary results align with previous mtDNA results that suggest (1) a significant divergence between populations on either side of the Mississippi River and (2) limited genetic diversity west of the Mississippi River [10, 11]. Future analyses comparing the allelic diversity of populations east and west of the Mississippi River would be insightful for better understanding these patterns.

\section{Limitations}

- The restricted sample size and geographic distribution for T. arizonensis and T. pomonae may underestimate potential polymorphic markers in these species.

- Markers not deviating from HWE in our initial screenings could potentially deviate in other populations, which may reduce the number of usable markers in certain genetic studies; on the other hand, markers deviating from HWE in the studied populations might not deviate in other populations, which would increase the number of markers.

- The presence of null alleles could be a result of potential phylogeographic structure in the populations studied (especially T. septentrionalis), as a result polymorphism may be underestimated.

- Sample sizes per marker for the Texas T. septentrionalis subset were smaller compared to Florida, which may limit our interpretations; however, reduced microsatellite diversity would be consistent with lower mtDNA diversity in western populations (Texas).

\section{Supplementary information}

Supplementary information accompanies this paper at https://doi. org/10.1186/s13104-020-05015-3.

Additional file 1. List of individual ant samples used in this study. The table includes individual sample name, host species, state of collection, general sampling location, and coordinates of collection location (unless the property was under private ownership).

Additional file 2. Details of the 10 Trachymyrmex septentrionalis polymorphic microsatellite markers analyzed for cross-amplification in Trachymyrmex arizonensis.

Additional file 3. Details of the 12 Trachymyrmex septentrionalis polymorphic microsatellite markers analyzed for cross-amplification in Trachymyrmexpomonae.

Additional file 4. Pairwise comparison results of the linkage disequilibrium analyses for all four species.

Additional file 5. Details of the 17 Trachymyrmex septentrionalis polymorphic microsatellite markers analyzed for Trachymyrmex septentrionalis ants across Texas (TX) and Florida (FL), highlighting the differences between two distant populations. Details include: marker name, size range of observed alleles given in base pairs (bp), number of individuals genotyped $(\mathrm{N})$, number of alleles observed (K).

\section{Abbreviations}

bp: Base pair; $\mathrm{H}_{\mathrm{e}}$ : Expected heterozygosity; $\mathrm{H}_{\mathrm{o}}$ : Observed heterozygosity; HWE: Hardy-Weinberg equilibrium; K: Number of alleles; Id: Linkage disequilibrium; mtDNA: Mitochondrial DNA; NGS: Next-generation sequencing; PCR: Polymerase chain reaction; PI: Probability of identity; SNPs: Single-nucleotide polymorphisms; $T_{m}$ : Annealing temperature.

\section{Acknowledgements}

Larry Gilbert, Steven Gibson and Rob Plowes facilitated collections at the University of Texas at Austin Stengl Biological Station and Brackenridge Field 
Laboratory. Joshua King and Andrea Lucky provided T. septentrionalis specimens from the Orlando and Gainesville, Florida areas, respectively. We thank Geoff Bender, Michele Lanan and Southwestern Research Station staff for providing logistical support and facilitating collection permits in the Coronado National Forest. This is paper No. 3 of the Ant Symbiosis Laboratory.

\section{Authors' contributions}

JNS and KK conceived the study, secured funding and permits, and collected samples. AEM, CR, and CS performed DNA extractions, PCR work, and tested/ optimized primer pairs on all species. AEM scored alleles and conducted data analysis. AEM and JNS led manuscript writing, and all authors edited the final manuscript. All authors read and approved the final manuscript.

\section{Funding}

The work was supported primarily by a National Science Foundation CAREER award to JNS (IOS-152822) and DEB-1354629 to KK. Additional funding was provided by the UTTyler Office of Sponsored Research to JNS and Texas Ecolab (www.texasecolab.org), who also provided access to private properties.

\section{Availability of data and materials}

The datasets analyzed during the current study are not presently public due to their use in ongoing publication, but the genotypic data for each sample are available upon reasonable request to the corresponding author.

\section{Ethics approval and consent to participate}

Not applicable. The current research did not involve human subjects, human material, or human data or animals.

\section{Consent for publication}

Not applicable.

\section{Competing interests}

The authors declare they have no competing interests.

\section{Received: 21 January 2020 Accepted: 11 March 2020}

Published online: 24 March 2020

\section{References}

1. Hölldobler B, Wilson EO. The leafcutter ants. New York: W.W. Norton; 2011.

2. Ješovnik A, Sosa-Calvo J, Lloyd MW, Branstetter MG, Fernández F, Schultz TR. Phylogenomic species delimitation and host-symbiont coevolution in the fungus-farming ant genus Sericomyrmex Mayr (Hymenoptera: Formicidae): ultraconserved elements (UCEs) resolve a recent radiation. Syst Entomol. 2017;42(3):523-42.

3. Schultz TR, Brady SG. Major evolutionary transitions in ant agriculture. Proc Natl Acad Sci USA. 2008;105(14):5435-40.

4. Schultz TR, Sosa-Calvo J, Brady SG, Lopes CT, Mueller UG, Bacci M Jr, Vasconcelos $\mathrm{HL}$. The most relictual fungus-farming ant species cultivates the most recently evolved and highly domesticated fungal symbiont species. Am Nat. 2015;185(5):693-703.

5. Sosa-Calvo J, Schultz TR, Brandão CRF, Klingenberg C, Feitosa RM, Rabeling C, Bacci M Jr, Lopes CT, Vasconcelos HL. Cyatta abscondita: taxonomy, evolution, and natural history of a new fungus-farming ant genus from Brazil. PLOS ONE. 2013;8(11):e80498.

6. Luiso J, Kellner K, Matthews AE, Mueller UG, Seal JN. High diversity and multiple invasions to North America by fungi grown by the northern most Trachymyrmex and Mycetomoellerius ant species. Fungal Ecol. 2020. https://doi.org/10.1016/j.funeco.2019.100878.

7. Moreau CS. Inferring ant evolution in the age of molecular data (Hymenoptera: Formicidae). Myrmecol News. 2009;12:201-10.

8. Seal JN, Kellner K, Trindl A, Heinze J. Phylogeography of the parthenogenic ant, Platythyrea punctata: highly successful colonization of the West Indies by a poor disperser. J Biogeogr. 2011;38:868-82.

9. Cardoso DC, Cristiano MP, Tavares MG, Schubart CD, Heinze J. Phylogeography of the sand dune ant Mycetophylax simplex along the Brazilian Atlantic Forest coast: remarkably low mtDNA diversity and shallow population structure. BMC Evol Biol. 2015;15(1):106.
10. Seal JN, Thiebaud J, Mueller UG. Gone to Texas: comparative phylogeography of two Trachymyrmex species along the southeastern coastal plain of North America. Biol J Lin Soc. 2015;114(3):689-98.

11. Mikheyev AS, Vo TL, Mueller UG. Phylogeography of post-Pleistocene population expansion in a fungus-gardening ant and its microbial mutualists. Mol Ecol. 2008;17(20):4480-8.

12. Martins J, Solomon S, Mikheyev A, Mueller U, Ortiz A, Bacci M. Nuclear mitochondrial-like sequences in ants: evidence from Atta cephalotes (Formicidae: Attini). Insect Mol Biol. 2007;16(6):777-84.

13. Sanllorente $O$, Ruano F, Tinaut A. Large-scale population genetics of the mountain ant Proformica longiseta (Hymenoptera: Formicidae). Popul Ecol. 2015;57(4):637-48.

14. Johansson H, Seppä P, Helanterä H, Trontti K, Sundström L. Weak population structure in the ant Formica fusca. PeerJ. 2018;6:e5024-e5024.

15. Doums C, Cabrera H, Peeters C. Population genetic structure and malebiased dispersal in the queenless ant Diacamma cyaneiventre. Mol Ecol. 2002;11:2251-64.

16. Smith CC, Weber JN, Mikheyev AS, Roces F, Bollazzi M, Kellner K, Seal J, Mueller UG. Landscape genomics of an obligate mutualism: concordant and discordant population structures between the leafcutterant Atta texana and its two main fungal symbiont types. Mol Ecol. 2019;28(11):2831-45.

17. Kellner K, Fernández-Marín H, Ishak HD, Sen R, Linksvayer TA, Mueller UG. Co-evolutionary patterns and diversification of ant-fungus associations in the asexual fungus-farming ant Mycocepurus smithii in Panama. J Evol Biol. 2013;26(6):1353-62.

18. Rabeling C, Gonzales O, Schultz T, Bacci M, Garcia M, Verhaagh M, Ishak H, Mueller U. Cryptic sexual populations account for genetic diversity and ecological success in a widely distributed, asexual fungus-growing ant. Proc Natl Acad Sci USA. 2011;108(30):12366-71.

19. Kellner K, Seal J, Heinze J. Sex at the margins: geographic parthenogenesis in the ant Platythyrea punctata. J Evol Biol. 2013;26(1):108-17.

20. Ellegren H. Microsatellites: simple sequences with complex evolution. Nat Rev Genet. 2004;5(6):435-45.

21. Morin PA, Luikart G, Wayne RK. SNPs in ecology, evolution and conservation. Trends Ecol Evol. 2004;19(4):208-16.

22. Puckett EE. Variability in total project and per sample genotyping costs under varying study designs including with microsatellites or SNPS to answer conservation genetic questions. Conserv Genet Resour. 2017;9(2):289-304.

23. Tsykun T, Rellstab C, Dutech C, Sipos G, Prospero S. Comparative assessment of SSR and SNP markers for inferring the population genetic structure of the common fungus Armillaria cepistipes. Heredity. 2017;119:371.

24. Kaiser SA, Taylor SA, Chen N, Sillett TS, Bondra ER, Webster MS. A comparative assessment of SNP and microsatellite markers for assigning parentage in a socially monogamous bird. Mol Ecol Resour. 2017;17(2):183-93.

25. Coates BS, Sumerford DV, Miller NJ, Kim KS, Sappington TW, Siegfried BD, Lewis LC. Comparative performance of single nucleotide polymorphism and microsatellite markers for population genetic analysis. J Hered. 2009;100(5):556-64

26. Weinman LR, Solomon JW, Rubenstein DR. A comparison of single nucleotide polymorphism and microsatellite markers for analysis of parentage and kinship in a cooperatively breeding bird. Mol Ecol Resour. 2015;15(3):502-11.

27. Fernández ME, Goszczynski DE, Lirón JP, Villegas-Castagnasso EE, Carino MH, Ripoli MV, Rogberg-Muñoz A, Posik DM, Peral-García P, Giovambattista G. Comparison of the effectiveness of microsatellites and SNP panels for genetic identification, traceability and assessment of parentage in an inbred Angus herd. Genet Mol Biol. 2013;36(2):185-91.

28. Fjerdingstad E, Boomsma JJ, Thorén P. Multiple paternity in the leafcutter ant Atta colomhica:a microsatellite DNA study. Heredity. 1998;80:118-26.

29. Fjerdingstad EJ, Boomsma JJ. Queen mating frequency and relatedness in young Atta sexdens colonies. Insectes Soc. 2000;47:354-6.

30. Villesen P, Gertsch PJ, Boomsma JJ. Microsatellite primers for fungusgrowing ants. Mol Ecol Notes. 2002;2(3):320-2.

31. Ortius-Lechner D, Gertsch PJ, Boomsma JJ. Variable microsatellite loci for the leafcutter ant Acromyrmex echinatior and their applicability to related species. Mol Ecol. 2000;9(1):114-6.

32. Villesen P, Gertsch PJ, Frydenberg J, Mueller UG, Boomsma JJ. Evolutionary transition from single to multiple mating in fungus-growing ants. Mol Ecol. 1999:8(11):1819-25. 
33. Rabeling C, Cover SP, Johnson RA, Mueller UG. A review of the North American species of the fungus-gardening ant genus Trachymyrmex (Hymenoptera: Formicidae). Zootaxa. 2007;1664:1-53.

34. Abdelkrim J, Robertson B, Stanton JA, Gemmell N. Fast, cost-effective development of species-specific microsatellite markers by genomic sequencing. Biotechniques. 2009;46(3):185-92.

35. Castoe TA, Poole AW, Gu W, Jason de Koning AP, Daza JM, Smith EN, Pollock DD. Rapid identification of thousands of copperhead snake (Agkistrodon contortrix) microsatellite loci from modest amounts of 454 shotgun genome sequence. Mol Ecol Resour. 2010;10(2):341-7.

36. Hudson ME. Sequencing breakthroughs for genomic ecology and evolutionary biology. Mol Ecol Resour. 2008;8(1):3-17.

37. Rabeling C, Bollazzi M, Bacci M, Beasley RR, Lance SL, Jones KL, Pierce NE. Development and characterization of twenty-two polymorphic microsatellite markers for the leafcutter ant, Acromyrmex lundii, utilizing Illumina sequencing. Conserv Genet Resour. 2013;6(2):319-22.

38. Kakazu S, Sanches A, Bacci M. Microsatellite loci characterized in the leafcutter ant Atta laevigata. BMC Res Notes. 2013;6(1):328.

39. Rabeling C, Love C, Lance S, Jones K, Pierce N, Bacci M Jr. Development of twenty-one polymorphic microsatellite markers for the fungus-growing ant, Mycocepurus goeldii (Formicidae: Attini), using Illumina paired-end genomic sequencing. Conserv Genet Resour. 2014;6(3):739-41.

40. Tschinkel WR, Seal JN. Bioturbation by the fungus-gardening ant, Trachymyrmex septentrionalis. PLoS ONE. 2016;11(7):e0158920.

41. Seal JN, Tschinkel WR. Distribution of the fungus-gardening ant, Trachymyrmex septentrionalis during and after a record drought. Insect Conserv Divers. 2010;3:134-42.

42. Solomon SE, Rabeling C, Sosa-Calvo J, Lopes CT, Rodrigues A, Vasconcelos HL, Bacci M, Mueller UG, Schultz TR. The molecular phylogenetics of Trachymyrmex Forel ants and their fungal cultivars provide insights into the origin and coevolutionary history of 'higher-attine' ant agriculture. Syst Entomol. 2019;44(4):939-56.

43. Castoe TA, Poole AW, de Koning APJ, Jones KL, Tomback DF, OylerMcCance SJ, Fike JA, Lance SL, Streicher JW, Smith EN, et al. Rapid microsatellite identification from illumina paired-end genomic sequencing in two birds and a snake. PLOS ONE. 2012;7(2):e30953.

44. Koressaar T, Remm M. Enhancements and modifications of primer design program Primer3. Bioinformatics. 2007;23(10):1289-91.

45. Untergasser A, Cutcutache I, Koressaar T, Ye J, Faircloth BC, Remm M, Rozen SG. Primer3-new capabilities and interfaces. Nucleic Acids Res. 2012;40(15):e115
46. Schuelke M. An economic method for the fluorescent labeling of PCR fragments. Nat Biotechnol. 2000;18(2):233-4.

47. Kearse M, Moir R, Wilson A, Stones-Havas S, Cheung M, Sturrock S, Buxton S, Cooper A, Markowitz S, Duran C, Thierer T, et al. Geneious basic: an integrated and extendable desktop software platform for the organization and analysis of sequence data. Bioinformatics. 2012;28(2):1647-9.

48. Peakall R, Smouse PE. GenAlEx 6: genetic analysis in Excel. Population genetic software for teaching and research. Mol Ecol Notes. 2006;6(1):288-95

49. Peakall R, Smouse PE. GenAlEx 6.5: genetic analysis in Excel. Population genetic software for teaching and research-an update. Bioinformatics. 2012;28(19):2537-9.

50. Rousset F. genepop'007: a complete re-implementation of the genepop software for Windows and Linux. Mol Ecol Resour. 2008;8(1):103-6.

51. Van Oosterhout C, Hutchinson WF, Wills DPM, Shipley P. micro-checker: software for identifying and correcting genotyping errors in microsatellite data. Mol Ecol Notes. 2004;4(3):535-8.

52. De Fine Licht HH, Boomsma JJ. Variable interaction specificity and symbiont performance in Panamanian Trachymyrmex and Sericomyrmex fungus-growing ants. BMC Evol Biol. 2014;14(1):244.

53. Fernandez-Marin H. Dynamic disease management in Trachymyrmex fungus-growing ants (Attini: Formicidae). Am Nat. 2013;181(4):571-82.

54. Chapuis M-P, Estoup A. Microsatellite null alleles and estimation of population differentiation. Mol Biol Evol. 2006;24(3):621-31.

55. Barth MB, Moritz RFA, Pirk CWW, Kraus FB. Male-biased dispersal promotes large scale gene flow in a subterranean army ant, Dorylus (Typhlopone) fulvus. Popul Ecol. 2013:55(4):523-33.

56. Sanetra M, Crozier RH. Patterns of population subdivision and gene flow in the ant Nothomyrmecia macrops reflected in microsatellite and mitochondrial DNA markers. Mol Ecol. 2003;12(9):2281-95.

57. Doums C, Cabrera H, Peeters C. Population genetic structure and malebiased dispersal in the queenless ant Diacamma cyaneiventre. Mol Ecol. 2002;11(11):2251-64

\section{Publisher's Note}

Springer Nature remains neutral with regard to jurisdictional claims in published maps and institutional affiliations.
Ready to submit your research? Choose BMC and benefit from:

- fast, convenient online submission

- thorough peer review by experienced researchers in your field

- rapid publication on acceptance

- support for research data, including large and complex data types

- gold Open Access which fosters wider collaboration and increased citations

- maximum visibility for your research: over $100 \mathrm{M}$ website views per year

At BMC, research is always in progress.

Learn more biomedcentral.com/submissions 